"An environmental assessment on hydropower development in Lithuania"

\begin{tabular}{|c|c|c|}
\hline AUTHORS & Jaunius Jatautas & \\
\hline ARTICLE INFO & $\begin{array}{l}\text { Jaunius Jatautas (2016). An env } \\
\text { development in Lithuania. Envir } \\
\text { 10.21511/ee.07(1).2016.03 }\end{array}$ & $\begin{array}{l}\text { ment on hydropower } \\
\text { ics, } 7(1), 24-33 \text {. doi: }\end{array}$ \\
\hline DOI & http://dx.doi.org/10.21511/ee.07 & \\
\hline RELEASED ON & Thursday, 24 March 2016 & \\
\hline JOURNAL & "Environmental Economics" & \\
\hline FOUNDER & LLC "Consulting Publishing Cor & erspectives" \\
\hline & & $\begin{array}{l}\text { 二- } \\
\text { =- }\end{array}$ \\
\hline NUMBER OF REFERENCES & NUMBER OF FIGURES & NUMBER OF TABLES \\
\hline 0 & 0 & 0 \\
\hline
\end{tabular}

(C) The author(s) 2022. This publication is an open access article. 
Jaunius Jatautas (Lithuania)

\title{
An environmental assessment on hydropower development in Lithuania
}

\begin{abstract}
Hydropower as a renewable energy source is a serious future alternative to organic fuel power and environmental protection. Its use is least damaging to the environment in comparison to thermal and nuclear power. Hydropower is a constant generating source and a type of energy that yields most return.

Based on this approach, the article assesses the hydropower development, reveals the reasons behind the hindrance of renewable energy source development, evaluates the tendencies and development prospects, draws the conclusions and presents the recommendations. This article reflects the concept of the latest findings of scientific research and practical interface. Planning, design, construction and operation of hydropower facilities, must be determined on how they may affect the natural state of water bodies, it is imperative to analyze and assess the environmental protection effectiveness. Natural water bodies should not be modified without an environmental impact assessment.
\end{abstract}

Keywords: development assessment, hydropower, renewable energy sources, hydropower development, tendencies, prospects.

JEL Classification: Q2, P28, P48.

\section{Introduction}

Hydropower is a developed technology of power production, which accounts for a significant portion of power production worldwide. Hydropower is a source of renewable energy (RE) and its use results in the smallest amount of environmental damage compared to heat energy and atomic energy. Different from wind or solar power, hydropower is a constant source of energy. Therefore, hydropower is an essential component of renewable energy as well as the whole energy sector. Hydroelectric power stations have long-term schemes, which allow the power stations to operate for over a century, and a short production process. They are also the most efficient power production technology with an effectiveness of 85-95 percent due to a simple production process, where mechanical energy is immediately converted into electric power (Tvaronas, 2013).

Although cost-efficiency of hydropower in Lithuania, a country of flatlands, is not very high, the rivers are valuable as an alternative source of energy. In near future, low-pressure hydroelectric power stations constructed on the rivers will play a significant role in electric power production in Lithuania. With regard to technical and economic possibilities, around 25-35 percent of minor hydropower resources have been used. However, taking into account the absolute prohibitions on damming most rivers, only 5 percent remain available for development (Punys, Ruplys, 2012).

(C) Jaunius Jatautas, Lithuania, 2016

Jaunius Jatautas, Master of Science, Mykolo Romerio University, Lithuania.
Major hydropower resources are the hydropower generated by the rivers Nemunas and Neris. They account for 80 percent of total technical potential. The potential of all other local hydropower resources, 475 rivers, is around $500 \mathrm{GWh}$ per year. Old micro hydroelectric power stations (MHS) are being reconstructed and new ones are being built with the purpose of using these resources in the future. Only a part of economic hydropower resources are being used today and therefore, there are significant opportunities for development of hydropower. According to power production, hydropower could be in the leading position for another 30 years until other RE achieve the market value, which makes the evaluation of hydropower development a relevant topic for today.

Problem. Constructing large hydroelectric power stations on major rivers (Nemunas and Neris) is more effective than small ones, but they are subject to more stringent environmental requirements. Therefore, development evaluation is an increasingly relevant issue in Lithuania due to the prevailing opinion that this economic activity has a negative impact on the environment, especially the ecological condition. This raises a question what environmental measures should be taken to achieve the development objectives and drives the search for particular measures for solving evaluation problems and finding the methods to overcome them, which should become the main directions of Lithuania's national energy development. The Lithuanian hydropower development potential has been favorably evaluated by researchers. Major issues are related to environmental protection, which results in a smallerscale development in Lithuania than in other EU countries. These circumstances lead the author of 
this article to search for solutions to the above problems to increase the balance of electric power sourced from hydropower. Hydropower development problems have been investigated according to Lithuanian and foreign countries research studies. This paper presents the comparison methods of the hydropower development problems in foreign countries.

Purpose: to carry out an evaluation of hydropower development in Lithuania.

\section{Objectives:}

- to evaluate the level of hydropower development in Lithuania;

- to evaluate ichthyologic studies;

- to evaluate the prospects of hydropower development.

Methods: legislation and document content analysis, analysis and synthesis of scientific literature, comparative analysis.

\section{Hydropower development state in Lithuania}

Hydropower is one of the main RE sources in the world, which supplies stable, financially effective and rapidly renewable type of energy to consumers (Guidebook on Cooperatives, 2014). In more advanced foreign countries, hydropower is developing alongside RE (Jager et al., 2015). The negative effects of hydropower development on the environment are minimal when using modern technology (Govorushko, Rupert, 2014). In Switzerland more than 55 percent of electricity is being produced from hydropower (Notter, 2015). Hydropower does not serve only for the production of energy. Dams (water reservoirs) create an infrastructure for other water economy sectors and alternative businesses related to dam environment, allow increasing river water content during draughts, preventing floods and developing recreation infrastructure. The best economic, social and environmental effect is achieved when river water resources are used to meet the needs of several water economy sectors. Therefore, energy production is among the most cost effective options in terms of profit and creates great infrastructure for other sectors. For example, a project was prepared for shipping development, according to which the River Nemunas could accommodate sea-river vessels, which would open up the shipping market to Western countries. Similarly, Kaunas Strategic Plan 2005-2015 planned for constructing a cargo port, improving the aesthetic appearance of the river and cleaning up its banks: building embankments and piers and thus attracting investment for tourism and recreation. The Ministry of Transport and Communications of the Republic of Lithuania has planned a water route over the River Neris up to Jonava town. It is an excellent opportunity to combine the needs of shipping and hydropower (Litbioma, National Renewable Energy Action Plan 2010-2020) supported by the European Union (EU).

EU supports such complex projects and the development of green technologies (wind, solar) and emphasizes the EU objectives to decentralize the production of energy. Hydropower improves the integration of alternative RE sources through water accumulation and energy release technology, which supplies stable, financially effective and rapidly renewable type of energy to consumers (Guidebook on Cooperatives, 2014). Hydropower is attractive in many aspects: hydroelectric power plants do not release $\mathrm{CO}_{2}$ or other pollutants, hydropower offers the lowest cost of electricity and "hydropower is also beneficial by providing the opportunity to use the hydropower stations for power balancing and energy reserves" (Jockus, 2011). This encouraged restoring the Lithuania's minor hydropower, the role of which is gradually increasing. Today, Lithuania has 92 operating minor hydropower stations (proposals of the Environmental Committee of the Seimas to the Lithuanian Government, 2014).

J. Jablonskis and A. Tomkevičienè (2004) analyzed and compared natural and technical hydropower resources, while discussing the problems of rivers or their sections that are most effective for hydropower development. The scientists also evaluated the ecological restrictions. The theoretic power and hydropower of rivers and slope surfaces were determined. The energy and performance of the water running in watercourses and over slopes was found to have 688.8 thousand $\mathrm{kW}$ potential power or 6.0 billion $\mathrm{kWh}$ of annual energy. The comparative indicators of river hydropower showed that the sections most effective in terms of hydropower were the ones with natural power exceeding $>20 \mathrm{~kW}$ per kilometer. There are 215 such river sections, which contain 25.1 percent of the total potential energy and annual hydropower of the country. However, certain prohibitions apply to these sections. Taking into account all environmental restrictions (nature reserves, parks, fish migration routes), only 87 effective sections in 65 rivers remain, accountting for 5.1 percent of potential power and hydropower of the country. The results obtained were used to compile a map of natural power per kilometer allowing to select an effective river section for a minor hydropower station (MHS) (Jablonskis, Tomkevičienè, 2004).

MHS development must be oriented at construction of new dams as well as the modernization of the existing hydroturbines, installing modern turbines on existing dams and damless reservoirs implement use of environmentally-friendly technologies (Juknys, 2010). During renovation of the existing hydroturbines, empirical calculation of electromechanical equipment price and the costs of different suitable turbines is 
imperative as well as precise cost estimate. According to O. Paish (2002), minor hydropower stations are among the most economic and effective. The European Commission seeks to increase the capacity of minor hydropower stations currently supported by the environmental policy. For example, L. Kosnik (2010) noted that minor hydropower stations are a considerable contribution to the RE sources potential of the US and reduces $\mathrm{CO}_{2}$ emissions. Small-scale hydropower development has a minimum environmental effect, especially due to the improvement of energy production from RE sources (Paish, 2002; Juknys, 2010; Aggidis, Luchinskaya, Rothschild, Howard, 2010; Kosnik, 2010). According to scientific studies and the EC position, energy production from RE sources uses state-of-the-art software and technology, the production has minimal negative effect on the environment. Recently construction has begun on damless, minor hydropower stations (MHS). In the author's opinion, this provides the basis for future simplification of MHS project implementation procedures.

The use of the Rivers Nemunas and Neris constitutes the greatest hydropower production. It accounts for 80 percent of total technical potential, meanwhile the hydropower potential of all other local hydropower resources (475 rivers) is around $500 \mathrm{GWh}$ per year. Existing MHS are being restored and new ones are being built on water bodies for their future use. Today, around 14 percent of technical and 25 percent of economical hydropower resources are being exploited. Therefore, there are extensive reserves available for hydropower development. According to power production, hydropower could be in the leading position for another 30 years until other RE achieve the market value. Hydropower, considered clean source of energy production, while emitting into the environment little amount of pollutants, including greenhouse gases. However, according to D. Streimikiene and J. Vveinhardt (2015) emission of gases contributing to "greenhouse" effect must be assessed. Therefore hydropower development has perspectives and its evaluation must be based on the principle of ecological efficiency - the least negative effect on the environment (Burneikis, Punys, 2000).

At present, the development of major hydroelectric power plants (over $10 \mathrm{MW}$ ) is not being planned. The majority of clean power from RE sources will be produced in cogeneration biomass stations and wind power stations. In order to achieve this objective, wind power stations with $500 \mathrm{MW}$ total power, biomass power stations of at least $105 \mathrm{MW}$, hydropower stations of $141 \mathrm{MW}$ and $10 \mathrm{MW}$ solar power stations will be equipped to operate in Lithuania in 2020 (National Energy Independence Strategy of Lithuania, Official Gazette, 10/07/2010 No. 80-4149). Constructing large hydroelectric power stations on the major rivers (Nemunas and Neris) is more effective than small ones, but they are subject to more stringent environmental requirements. Therefore, development and environmental impact assessment is an increasingly relevant issue in Lithuania due to the prevailing opinion that this economic activity has a negative impact on the environment, especially the ecological condition. Hydropower development is proceeding quickly, pointing Suhardiman, D., M. Giordano and F. Molle (in 2015), thus highlighting the continuing scientific evaluation of the role of these researchers emphasize the fact that although hydropower development is often criticized, made scientific development assessments can convincingly demonstrate the benefits of hydropower development (Suhardiman et al., 2015). This raises a question what environmental measures should be taken to achieve the development objectives and drives the search for particular measures for solving evaluation problems and finding the methods to overcome them, which should become the main directions of Lithuania's national energy development. The Lithuanian hydropower development potential has been favorably evaluated by researchers. Major issues are related to environmental protection, which result in a smaller-scale development in Lithuania than in other EU countries. These circumstances lead the author of the article to search for solutions to the above problems with a view of increasing electricity generation from hydropower energy production balance.

Environmental changes caused by hydropower had been monitored for several decades. Many studies have been carried out to analyze the changes in the rivers and environmental problems caused by hydropower stations. The environmental effect of hydropower stations is a long-term, dynamic process and therefore, hydropower-related research is being carried out on a regular basis. International non-governmental organizations (International Rivers Network) analyze and present the evaluations of global hydropower problems and encourage preserving and restoring natural rivers. However, there is a lack of a new Lithuanian hydropower development and environmental effect evaluation model, which has not been sufficiently analyzed in scientific literature.

Hydropower development is supported by the European Commission, international EU legislation is favorable for hydropower and development of new water reservoirs, while through scientific progress seeking to ensure the principles of sustainable growth. Sustainable growth concept also provides the basis for the Lisbon Strategy followed by all EU countries. However, the sector of minor hydropower resources is facing new challenges and it requires a 
new model of thinking and creativity in solving the issues of constructing new water reservoirs. There is an unrealized potential of small and micro hydropower electric generation, which is environmentally acceptable and could have a positive effect on the environment and fishery. It is in line with EU objectives and has multiple benefits for local residents. With the purpose to achieve these objectives, a European minor hydropower development project RESTOR Hydro was created. The project aims at increase renewable energy production from small and micro hydropower by identifying and restoring suitable historical sites, mills and hydropower stations that are currently inoperative. RESTOR Hydro map provides authoritative information on the hydropower potential of historic water wheels and mills, inoperative hydropower stations, weir sites, and other lateral river structures, covering the entire EU-28 region. The data collected are freely available to regional authorities, municipalities, local hydropower developers, researchers and any other interested members of the public. Restoration programs of abandoned water mills and hydropower stations will be implemented in eight countries: Belgium, France, Greece, Italy, Lithuania, Poland, Slovenia and Sweden.

Project objectives:

- supply electricity to local communities and the European grid on a sustainable and economically viable basis;

- raise awareness that small hydropower is an environmentally sustainable and beneficial part of our renewable energy mix;

- demonstrate the attractiveness of small hydropower as a local investment vehicle, bringing revenue to local communities and contributing to energy independence, while preserving our historical heritage and the environment;

- contribute to significant, stable renewable energy generation throughout the EU (Unleash Microhydro Potential in Europe!, 2014).

Unrealized potential for small and micro hydropower generation exists in Europe's thousands of historic mills, water wheels, inoperative hydropower stations, weirs and other lateral structures in rivers. Repowering abandoned sites results in the generation of hydroelectric power, both for local use and for injection to the European electrical grid. This simultaneously leads to increasing electricity production from renewable sources, energy independence and grid stability. Besides enhancing energy supply security, the creation of local energy sources gives a boost to local economies, provides income sources and creates jobs. Therefore, the RESTOR
Hydro project identifies the most relevant sites suitable for refurbishment and stimulates investment through the development of a market-driven model for regional cooperatives. Identification and refurbishment follow specific methodological guidelines, taking into account environmental, economic and social aspects, and bring benefits to local residents (Unleash Microhydro Potential in Europe!, 2014; Guidebook on Cooperatives, 2014).

As mentioned above, "hydropower is also beneficial by providing the opportunity to use the hydropower stations for power balancing and energy reserves" (Jockus, 2011). The energy system must have a power balance and a possibility of reserves. For example, balancing problems arise when wind power exceeds 30 percent of total power consumption in the general balance. In Lithuania, this proportion is considerably smaller, but the number of wind power stations may increase three times in Lithuania: around 1,200 MW installed inland and around 1,000 MW - in the exclusive economic zone in the Baltic Sea or the coastal area, where a scheme has been prepared and strategic evaluation of environmental effect of a water area scheme has been carried out (Law on Renewable Energy Sources (LRES) of the Republic of Lithuania, 2011). Therefore, almost half of electric power consumed in Lithuania would be produced by wind, which requires a reliable regulation of wind power station imbalances caused by their variable production mode. Hydro accumulation (hydro accumulation power station (HAS)) is seeing a revival in Europe due to the development of power generators using unstable RE sources (wind, sun). Regardless of various electric power accumulation methods available in the market (mechanical (compressed air), chemical and electrochemical (batteries, fuel cells, hydrogen production)), hydro accumulation today is one of the most efficient methods. HAS accumulates surplus energy of unstable power generators well and maintains a necessary network frequency.

In the next decade, most new HASs will be installed in Germany, Austria, and Switzerland, which also have many wind power plants. Their regulation allows a lot of flexibility and results in hardly any loss in electric power. Since accumulation hydropower plants are currently most suited for balancing irregular power and large wind parks, which are being constructed in Sweden, Germany and Denmark, will require a sudden increase in power balancing resources, the completed Kruonis HAS would prove beneficial. Lithuania is a viable option due to Kruonis HAS, because its capacity may double and installed power may increase to 1,800 MW, said M. Zuber, an energy expert from Germa- 
ny (2011). Modernization of HAS would allow Lithuania to ensure network balancing opportunities in the future. Thus, after 2020, the role of the power station will remain the same, electric power production and consumption balancing and energy reserve will be necessary and therefore, Kruonis HAS will not lose its significance after Lithuania joins the European network. The development of wind and solar power will inevitably demand network balancing, which can be ensured by hydro accumulation power plant capacities (Bačiauskas, Borisevičius, Gaitanži，2010; Scowcroft, Nies，2011; Jockus, 2011; Zuber, 2011; Punys, Ruplys, 2012; Eurostat 2014). However, the author notes that the Lithuanian policy does not provide for sustainable development of RE sources, i.e., after wind power stations of more capacity are installed in the coastal area and off shore, this energy should be balanced by hydro accumulation power plants, and not fuel oil power plants. There is no separate office for coordination of this process in Lithuania; the mechanism of public management and its lack of adaptation to new technologies that require flexibility are also worth criticism.

\section{Ichthyological studies}

Ichthyology is a branch of zoology dealing with fish, their prevalence and evolution. An ichthyological reserve is a territory, usually a water body, where fish are protected. Ichthyological reserves protect spawning grounds as well as animal and plant species found in these territories and ensure a favorable condition of the protected species. Ichthyological studies help to rationally manage the fish economy and develop fish culture and fishing (Rosenthal, Schnack, 2015; Keith, Barclay, 2015).

Ichthyological studies are carried out in Lithuanian rivers, which help to evaluate the quantity of fish in the rivers. Every year, the fish condition is determined in around 150 selected locations of rivers. According to the results of the studies, the quantity of fish in Lithuanian rivers is gradually increasing, their condition is improving and salmon and brown trout populations are growing. It is a result of lower environmental pollution, environmentalist effort and release of artificially bred fish into the water bodies of Lithuania (Mokslininkai džiaugiasi - Lietuvos upèse pamažu daugèja žuvų (Scientists Pleased with Growing Numbers of Fish in the Lithuanian Rivers, 2013).

Permits and restrictions of hydroelectric project construction are in place to protect the fish in Lithuania. Article 14 of the Law on Water of the Republic of Lithuania (2003) "Construction and Use of Hydrotechnological Facilities" stipulates: "Hydrotechnological Facilities necessary for water protec- tion, water use, protection of the environment against negative effects of water, hydropower and other needs may be constructed on water bodies ...construction of dams on the rivers or sections of the rivers significant for protection of protected fish species is prohibited". The benefits of hydrotechnological facilities on water environment protection is also noteworthy.

Increasing the scale of fish protection and promoting national hydropower development require environmental, ichthyological and fishery studies. In order to increase the level of environmental studies, the efforts must be much more intense than they are today. For example, in the procedure set by the Lithuanian Government, the National Ichthyological Reserves (Dubysa, Jūra, Merkys, Minija, Šventoji, Veiviržas and Žeimena) Border Plan Preparation Program was completed in 2012. The current condition was evaluated by carrying out the analysis of the landscape and natural values. The borders of ichthyological reserves as well as buffer zones of protected areas were delimited. Solutions for biological diversity (especially ichthyofauna, European Community significant species and their habitats) and landscape protection development were prepared. Individual regulations may also be prepared under necessity (National Ichthyological Reserves Border Plan Preparation Program, 2010). However, the ichthyologists see the construction of any hydrotechnological facilities as irreparable damage to salmon and other migrating fish populations. They believe, Lithuania would lose salmon fishing quotas in the Baltic Sea and would be subject to sanctions for destroying a natural salmon population. It would also cause damage to the resources of commercial fish such as vimba, river lamprey and asp. With regard to these statements, P. Punys and K. Sivickis (2004) explain than small dams in Lithuania with modern fish protection equipment will not cause damage to fish. "Today, the environmental specialists can no longer deny the effectiveness of Kavarskas Hydropower Station fish ladder," said the scientists. Contemporary water engineering technologies, construction of fish ladders and dam bypass canals and other advanced measures do not have a negative effect on fishery. Therefore, the ichthyology specialists must increase their awareness of fishery and hydropower advancement and new technologies. Ichthyology and hydropower studies should be based on water ecosystem productivity evaluation, modelling and forecasting in accordance with water environment law and national policy.

Although national hydropower development is encouraged, the restrictions on construction of dams on the River Nemunas as well as ecologically and 
culturally significant rivers today are the shortcomings of the national policy. Prohibitions have been issued on damming and regulating natural rivers, changing their course and the natural water level of lakes in natural and complex reserves. Prohibition of construction (reconstruction) of dams on ecologically and culturally significant rivers has considerably restricted the use of hydropower. While the EU policy directives encourage the construction of dams, some Lithuanian laws prohibit the construction of new hydropower stations or adapting existing dams for the production of power. Meanwhile in "... developed foreign countries hydropower is being developed along with RE sources..." (Jager et al., 2015).

Today, section 3 of Article 14 of the Law on Water of Lithuania contravenes with the right to carry out an environmental impact assessment (EIA) granted by the Law on Environmental Impact Assessment of the Proposed Economic Activity of the Republic of Lithuania as well as with the natural right to engage in economic activity. Therefore, each case of use or protection of a river or its section must be analyzed individually by carrying out an environmental impact assessment and the Laws on Construction, Territorial Planning, Protected Areas, Protection of Immovable Cultural Heritage, and Regional Development must be amended. The Law on Water also contravenes with the provisions of the Law on Protected Areas of the Republic of Lithuania, which regulates the construction of dams or reservoirs (Article 9): prohibits the construction or permits it under certain conditions (e.g., restoration of immovable cultural heritage values). However, taking into account the protected values, this law provides for a type of zoological reserves protecting the fish (ichthyological reserves), which is subject to the above restrictions. Meanwhile the "list of ecologically and culturally significant rivers or their sections" referred to in section 3 of Article 14 of the Law on Water does not have any legal basis applicable to reserves.

Currently, the majority of hydrotechnological facilities (dams) have deteriorated and there are virtually no predams. Approximately 80 of these structures and dam remnants, including various weirs, are in rivers of ichthyological significance and rebuilding them is therefore prohibited by the Law on Water. If a change in this position was allowed, it could enable the restoration of natural assets and ruined landscapes in the process of implementing the provision in the Law on RE stipulating that the installed capacity of hydropower plants connected to the grid must be increased to $141 \mathrm{MW}$ by 2020 . There will be no need for the state to make sizeable investments in the removal of remnants of former hydroelectric stations for the purpose of improving fish migration routes. State investments such as this can be avoided by attracting private capital and creating a legal framework that would provide for the rebuilding of small hydroelectric stations, which would also create opportunities for developing rural tourism, water recreation and more diversified rural business. It has been scientifically proven that the use of river water for hydropower can increase the prevalence and migration of fish as well as improve the rational management of fish farming (Punys, Ruplys, 2012).

Hydropower advocates are interested in reconstruction of water mills and development of small hydropower stations, because water mills are generally suitable for producing power. Lithuania has compiled a list of the remains of former water power stations, which must be removed in order to improve fish migration conditions, which requires investment. Private capital investment could be attracted by creating the conditions to install small hydropower stations. Therefore, with a view of preserving and restoring historical water mills instead of destroying them, generating income should be allowed. Research has shown that low pre-dams built at a height within the natural range of a river's water level fluctuation (up to $5 \mathrm{~m}$ in height - upper limit of annual floods) and with all the necessary environmental measures that meet environmental requirements do not have a significant impact on river eco-systems (Punys, Ruplys, 2012).

Analyzing the ichthyological studies, the author noted that the assumption to construct hydropower plants must be prohibited in ecologically and culturally significant rivers or their sections were not correct. Therefore, the benefits of hydropower must be explained and awareness that minor hydropower is environmentally useful and friendly, should be raised. The studies must be carried out on a sustainable and economically viable basis with three levels of advance planning of hydropower stations. Thus, the rivers or their sections would be sorted into favorable for building hydropower stations, less favorable and not favorable. It means that instead of a stringent prohibition to dam the rivers, a selective permission system would be proposed, which would not hinder the construction of hydropower plants. Only carrying out the environmental impact assessment studies would allow obtaining the objective information on the existing condition of rivers and future effect on fish prevalence and migration. One would agree that ichthyological reserves and spawning grounds of salmon and other rare species of fish should be unfavorable locations for dams. Therefore, the environmental impact assessment model must be reviewed and adapted to promote energy 
from RE sources, first of all, by allowing to carry out EIA in protected areas. The environmental legislation (first, the Law on Water) and the categories of protected areas should also be reviewed.

\section{Hydropower development assessment}

Hydropower is one of the most important RE sources, which provides the greatest global envi- ronmental benefit, if reasonable environmental criteria are observed. The Water Framework Directive (2000) will provide a unique opportunity to improve the regulation of public institutions and restore the ecological status of water bodies in the European Union (Ioris, 2015). Since 2000, global hydropower resources have increased around 30 percent (TWh).

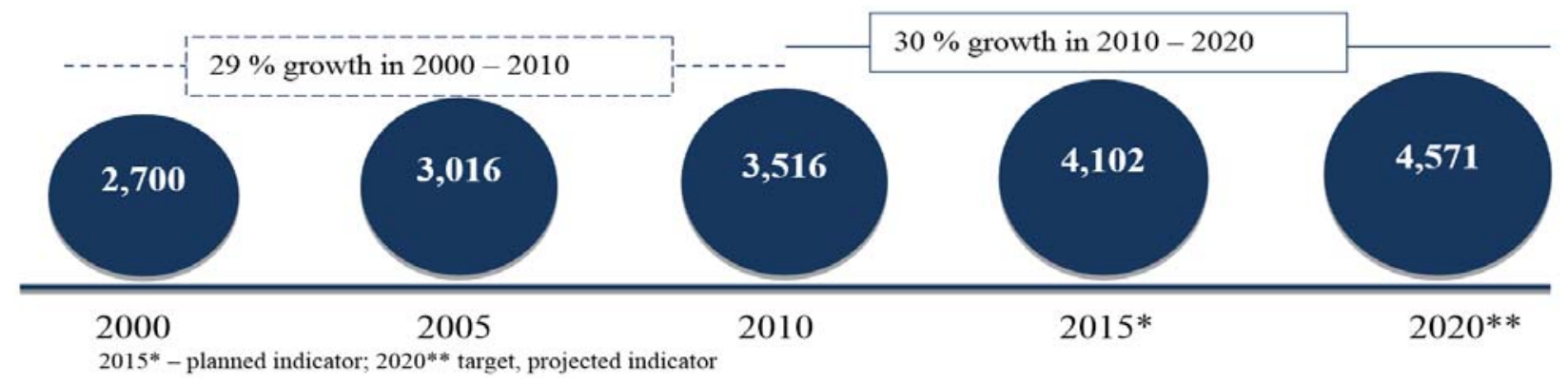

Fig 1. Global hydropower dynamics and tendencies, TWh (adapted by the author from Tracking Clean Energy Progress, 2013)

Global forecasts show that the demand of energy will increase and therefore, the development of hydropower will increase as well. Today, the largest producers of hydropower are Canada, China, Russia, and the United States of America. China's installed hydropower considerably exceeds the average 30 percent of other countries. In some countries (Iceland, Nepal and Mozambique), hydropower also accounts for more than 30 percent of total electric power production. The development of hydropower will be even more extensive in India and Brazil (World Energy Resources, 2013). The author notes that faced with increasing demand of electric power, the world is looking into different technologies of accumulating electric power and smart grids are developing along with accumulation technologies. The global experience shows that the impact of hydropower is growing and the best economic effect is achieved by complex use of river water resources: electric power production, shipping, protection against floods, etc. Dams are necessary for cargo shipping - to ensure the technical parameters of a water route.

After joining the EU, Lithuania became a full member of the Hydropower Association (ESHA). Ties with the International Hydropower Association have been established as well as with hydropower and similar renewable energy and water engineering associations in the US and other countries. The country communicates with other global-level hydropower centers in China, India and Canada, exchanges information, participates in internships, conferences, workshops, implements joint hydropower development projects and publishes scientific and informational articles. The hydropower interests of the country are represented in the Water Council of the Lithuanian Academy of Sciences and the Hydropower Commission (Lietuvos hidroenergeti- ka, 1996-2011). With a view to develop RE sources, the Ministry of Energy with a Renewable Energy Sources Department was established in Lithuania. Hydropower has great potential for development and is a significant RE source, however, it is not being sufficiently developed in Lithuania, the attention it receives is not adequate and the research into it is not considered authoritative. Lithuania still does not have an officially approved hydropower strategy and development Program and the Law on Water and other legislation are not promising for development. Therefore, the development of hydropower is problematic and hardly encouraged by the state due to the assumption that this economic activity has a negative effect on the environment, especially the ecological condition. Since the surplus of electric capacity in country has recently doubled the need, this issue was not of most importance. However, after closing down the Ignalina Nuclear Power plant, the issues of electric capacity, especially peak capacity, and the production of electric power have become relevant. Therefore, most prospective are combined cycle and gas turbine power stations and economical hydropower stations.

According to foreign researchers, the development of hydropower is hindered by many obstacles. According to Verburggen et al. (2010), the obstacles are the circumstances and their features created by men. The obstacles may be intentional and unintentional. S. Reddy and J.P. Painuly (2004), analyzing the obstacles for RE sources development, have classified them by field of activity and elaborated on the players and prospects. They propose classifying the obstacles into six groups: awareness, information, market, technology, finance and economics. J.R. Moreira (2003) specified that development of RE sources was hindered by the actions of the Government and the fol- 
lowing obstacles: economic and financial, institutional and legal, environmental, and sociopolitical. J. Weber (1997) agrees and distinguishes the institutional obstacles caused by political institutions such as the Government and local government.

The development of hydropower in Lithuania is hindered namely by the Government, the Seimas and local governments, which act under biased information that hydropower means "drowning Lithuania", "eutrophication and silting up of water bodies" and "eradication of fish and the whole ecosystem". The arguments of water and hydrotechnology researchers are hardly taken into account. Even when considering the Law on Renewable Energy Sources (2011), the top leaders of the country and the Government officially stated that "We should turn to energy sources that are less damaging to nature than hydropower stations..." and that "society should not be instigated by hydropower development and building dams on significant rivers" (Lietuvos hidroenergetika, 1996-2011). After the amendments to the Law on Water were adopted in 2004 and a Resolution "On Approval of the List of Ecologically and Culturally Significant Rivers or Their Sections" of the Government of Lithuania was adopted on 8 September 2004, the development of hydropower and other water industries has nearly come to a halt. The professional grounds of the amendment to the Law on Water is that water reservoirs will soon silt up, the delta of the Nemunas will be flooded and the historical archaeological and even urban heritage will be endangered. However, different from current leaders and lawmakers of the country, society supports the development of hydropower. The advocates of hydropower believe that the use of water resources can be sustainable by combining production of renewable energy and protection of river ecosystems as well as developing water recreation and other related businesses.

Today, the development of large hydropower stations (HS) is not planned at all. A law protecting the major rivers (Nemunas, Neris) is applied in Lithuania. It prohibits building dams on these rivers, which are necessary for hydropower stations. Small development opportunities are still available to small and micro hydropower stations (MHS). We must admit that HS and MHS have many qualities and have a positive effect on the nature. The use of such stations instead of the widespread polluting power production methods would allow avoiding a considerable amount of pollutant emissions into the atmosphere. D. Williams (2011), the President of the British Hydropower Association (BHA), said that "MHS are among the most economical and effective RE sources in comparison to solar, wind and ocean (tidal) power technologies" (Davies, 2011). T. and S. Abbasi (2011) noted that that MHS development has regained interest in the world. First, it is the cleanest source of energy with very little or no negative effects on the environment. The researchers present a comprehensive analysis, whether such prevalence of MHS is justifiable, and a substantiation of public benefit of MHS by the use of favorable modern technologies. The recommendations based on the research results are increasing the height of MHS dam, more effective use of reservoir resources during the wet season and replenishing the water loss from the neighboring hydrographic network. Also, more advanced turbines should be used and the technology must be better adapted to natural discharge cycle of the river. These measures allow increasing MHS power production without damage to the environment.

Although the present situation is not favorable for hydropower development, the above reasons create a pretext to look at the possibilities of using the rivers for hydropower purposes once again. The Seimas and the Government of Lithuania are starting to evaluate the situation and therefore, it is likely that more promising legal conditions will be adopted for the development of river water businesses by evaluating each water project individually according to EU provisions of environmental impact assessment, taking into account the peculiarities of a country and not condemning beforehand, as the current provisions do. Therefore, it is recommended to foster an objective approach, because current legislation may restrict this advanced source of renewable energy. Furthermore, the administrative procedures must also be improved (the period for obtaining a license and concession is prolonged), because a simpler, centralized, more flexible and uniform system could facilitate the hydropower development. With a view of achieving these objectives, at least three levels of advance hydropower planning should be applied to rivers. The rivers or their sections would be classified into favorable for building hydropower stations, less favorable and not favorable. Thus, instead of a stringent prohibition to dam the rivers, a selective permission system could be legalized, which would not hinder the construction of hydropower plants in all cases, when it is demonstrated that their environmental effect would be low or none. Only carrying out the environmental impact assessment studies would allow obtaining the objective information on the existing condition of rivers and future effect on physical, natural, social and cultural environment, if the rivers are dammed. It would also serve as a basis for the requirement of balanced use of water resources, which would encourage 
multiple uses and ensure the participation of all stakeholders in hydropower development.

\section{Conclusions}

Legal prohibitions do not allow construct the dams on nearly all large, medium and small rivers of Lithuania. Other rivers, where pre-dams are allowed, have low discharge and hardly suitable for energy production. The development of hydropower in Lithuania is hindered by the Government, the Seimas and local governments, which act under biased information. Lithuania still does not have an officially approved hydropower strategy and development Program and the Law on Water and other legislations are not favorable for development. The development of hydropower is hardly encouraged by the state due to the assumption that this economic activity has a negative effect on the environment, especially the ecological condition. Hydropower has great potential for development and is a significant $\mathrm{RE}$ source, however, it is not being sufficiently developed in Lithuania, the attention it receives is not adequate and the research into it is not considered authoritative enough to have an effect on the political will.

Ichthyological studies help in developing the fish culture, increasing fish protection, improving the fish migration conditions, however, they are not yet sufficient. Research shows that the use of river water for hydropower can help to rationally manage the fish farming. Today, there is a lack of an accurate hydropower potential component assessment method. Generally, hydropower activity is reduced for the rivers crossing the protected areas instead of an accurate assessment of the locations, where hydropower would cause damage and therefore would be prohibited.

Hydropower is one of the most important RE sources, which provides the greatest global environmental benefit. Therefore, an assessment of development prospects shows that the energy demand of electric power will grow, stimulating the hydropower development as the political powers change.

\section{Recommendations}

Reasonable use of modern technological environmental measures do not have a negative effect on water ecosystems and therefore, it is recommended to reconstruct the dams of former water mills and sawmills by adapting them for electric power production and thus preserving the heritage objects. These changes would allow using natural water resources more effectively, restoring deteriorated natural and cultural heritage objects and shaping an attractive landscape. A selective license and permission system must be legalized, which would not hinder the construction of hydropower stations.

When increasing fish protection, ichthyological studies should be oriented at rational management of fish economy and an accurate hydropower potential component assessment method. Each case of use or protection of a river or its section must be analyzed individually by carrying out an environmental impact assessment. Only carrying out the environmental impact assessment studies would allow obtaining the objective information on the existing condition of rivers and future effect on fish prevalence and migration. The ichthyologists believe that a list of especially sensitive locations should also be compiled.

Hydropower development assessment shows that as the electric power demand increases, the hydropower development will increase as well. Therefore, water resources must be used sustainably by combining renewable energy production and protection of the river ecosystems. It is recommended to foster an objective approach to hydropower as an attractive means of local investment. The administrative procedures must be improved and the hydropower development must be facilitated by applying at least three levels of advance hydropower planning to rivers. The awareness must be raised that minor hydropower is an environmentally friendly, sustainable and economically beneficial renewable energy source, which contributes to environmentally safe production of electric power in the European Union.

\section{References}

1. Abbasi, T., Abbasi, S.A. (2011). Small hydro and the environmental implications of its extensive utilization, Renewable and Sustainable Energy Reviews, 15 (4), May, pp. 2134-2143.

2. Aggidis, G.A., Luchinskaya, E., Rothschild, R., Howard, D.C. (2010). The costs of small-scale hydro power production: Impact on the development of existing potential, Journal of Renewable Energy, 35 (12), December, pp. 2632-2638.

3. ASDF Paish O. (2002). Small hydro power: technology and current status, Renewable and Sustainable Energy Reviews, 6(6), December, p. 537.

4. Baciauskas, V., Borisevicius, A., Gaitanzi, A. (2010). Renewable energy resource potential usage Lithuania. National Audit Office of Lithuania, the National Audit Report. January 15. No. VA-P-20-2-1. Vilnius, p. 63 [in Lithuanian].

5. Burneikis, J., Punys, P. (2000). Lithuania hydropower development trends, Science and Life, 4 [in Lithuanian].

6. Davies, S. (2011). Big ideas for small hydro, Academic Journal Engineering \& Technology, 6 (1), February, pp. 52-54. 
7. Eurostat, Energy from renewable sources: tables and figures. Source data for tables, figures and maps (MS Excel) The statistical office of the European Union, EU 28 countries, 2014. Available at: phttp://epp.eurostat.ec. europa.eu/statistics_explained/index.php/Energy_from_renewable_sources [accessed on 03/11/2014].

8. Guidebook on Cooperatives (V6.2). (2014). Co-funded by the Intelligent Energy Europe Program of the European Union. Brussels.

9. Hydropower in Lithuania,15 years of activity. Vilnius, Lithuanian Hydropower Association, 1996-2011, pp. 62 [in Lithuanian].

10. Jablonskis, J., Tomkevicienè, A. (2004). Lithuanian small hydro development opportunities, Energy, 2, pp. 40-46 [in Lithuanian].

11. Jockus, A., Kruonis, P.S.P. (2011). Perspective Mist, Lithuanian news 18/07/2011 [in Lithuanian].

12. Juknys, R. (2010). Renewable energy development opportunities for sustainable development, Research papers, Sustainable Development Strategy and Practice, 1(4), pp. 4-10 [in Lithuanian].

13. Keith, C.M., Barclay, S. (2015). Aqua Heiko Bleher Ichthyology, International Journal of Ichthyology, 21(2), April 15, pp. 54-65.

14. Kosnik, L. (2010). The potential for small scale hydropower development in the US, Academic Journal Energy Policy, October, 38 (10), pp. 5512-5519.

15. Law on Energy from Renewable Resources of the Republic of Lithuania, 12 May 2011, No. XI-1375. Official Gazette No. 62-2936. As last amended on 23/07/2014, No. XI-1375, 10/07/2014, No. XII-847, 24/04/2014, published on 02/05/2014, TAR, i.k. 2014-05001.

16. LITBIOMA. (2008). Lithuanian Association of Biomass Energy. Final report. Vilnius, [in Lithuanian].

17. Moreira, J.R. (2003). Prepared for the Fifth Workshop of Latin American Biomass Network (LAMNET) held in Morelia, available at: http://cenbio.iee.usp.br/download/publicacoes/policies_for_promotion.pdf [accessed on 23/12/2014].

18. National Energy Independence Strategy approved by Resolution No. XI-2133 of 26 June 2012. Vilnius, Ministry of Energy of the Republic of Lithuania, 2012. Official Gazette, 10/07/2012, No. 80-4149.

19. National Ichthyological Reserves (Dubysa, Jūra, Merkys, Minija, Šventoji, Veiviržas and Žeimena) Border Plan (Adjustment of Existing Reserve Borders) Preparation Planing Program. Approved by Order No. V-229 of 12 October 2010 of the Director of the State Service for Protected Areas under the Ministry of Environment.

20. Proposals of the Environmental Committee of the Seimas of the Republic of Lithuania to the Government regarding the issues of environmental effect of hydropower and river level regulation near hydropower stations. Public information release, 24 April 2014. Available at: http://www3.lrs.lt/pls/inter/w5_show?p_r=4463\&p_k= $1 \& p \_d=146903$ [accessed on 24/11/2014].

21. Punys, P., Ruplys, B. (2012). The country's hydropower: perished perspective. Lithuanian Confederation of renewable energy, [in Lithuanian].

22. Punys, P., Sivickis, K. (2004). Legislation and environmental requirements analysis Lithuanian hydropower development, Lithuanian University of Agriculture and Lithuanian Agricultural University Water Management Institute, Academic Work, 27 (47), pp. 57-70, [in Lithuanian].

23. Reddy, S., Painuly, J.P. (2004). Diffusion of renewable energy technologies - barriers and stakeholders' perspectives, Renewable Energy, 29, pp. 1431-1447.

24. Resolution No. 1144 of the Government of the Republic of Lithuania of 8 September 2004 On the Approval of the List of Ecologically and Culturally Significant Rivers or Their Sections. (Official Gazette, 2004. No. 137-4995).

25. Rosenthal, H., Schnack, D. (2015). Fisheries Impact Factor, Academic Journal of Applied Ichthyology, Blackwell Verlag GmbH Online, August, 31(4), pp. i-ii, 587-819.

26. Scientists pleased Lithuanian rivers slowly growing fish (2013). 22 October, available at: http:/grynas.delfi.lt/ aplinka/mokslininkai-dziaugiasi-lietuvos-upese-pamazudaugeja-zuvu.d?id=63094596 [accessed on 01/06/2015] [in Lithuanian].

27. Scowcroft, J., Nies, S. (2011). Hydro in Europe: Powering Renewables. Fill report, Union of the Electricity Industry, Eurelectric, Brussels.

28. Streimikiene, D., Vveinhardt, J. (2015). Community based social marketing for implementation of energy saving targets at local level, The Amfiteatru Economic Journal, 17(39), May, pp. 723-734.

29. Tracking Clean Energy Progress. (2013). Input to the Clean Energy Ministerial International Energy Agency, OECD/IEA publications, Cedex 15, Paris, p. 151.

30. Unleash Microhydro Potential in Europe! Restor Hydro 2014 (2014). European Small Hydropower Association (ESHA), Renewable Energy House, Brussels. Available at: http://www.restorhydro.eu/en/about-the-project/aboutrestor-hydro/ [accessed on 12/12/2014].

31. Verbruggen, A., Fischedick, M., Moomawc, W., Weird, T., Nada, A., Nyboer, J., Sathaye, S. (2010). Renewable energy costs, potentials, barriers: Conceptual issues, Energy Policy, 38, pp. 850-861.

32. Weber, L. (1997). Some reflections on barriers to the efficient use of energy, Energy Policy, 10, pp. 833-835.

33. World Energy Resources. (2013). World Energy Council, Published by World Energy Council London W1B 5LT United Kingdom, 466 p.

34. Zuber, M. (2011). Renaissance for Pumped Storage in Europe, HRW HydroWorld, 19(3), July 1. 